\title{
Instantaneidad y estereoscopía: el viaje fotográfico a través de España de la compañía parisina J. Lévy et Cie, a finales del siglo XIX*
}

\author{
JOSÉ ANTONIO HERNÁNDEZ LATAS \\ Investigador de la Agencia Aragonesa para la Investigación y el Desarrollo (ARAID)** \\ Universidad de Zaragoza \\ jahernan@unizar.es
}

\begin{abstract}
Resumen:
A mediados de la década de 1880 la compañía fotográfica parisina J. Lévy et Cie recorrió España a lo largo de sucesivos viajes, poniendo en práctica por vez primera, de un modo sistemático, la técnica de la instantánea. Es decir, haciendo uso de la moderna emulsión al gelatino-bromuro de plata, descubierta por Richard L. Maddox en 1871, y perfeccionada con sucesivas aportaciones (Kennet, 1874; Harper Bennet, 1878; Monckhoven, 1879). Aunque tradicionalmente se viene atribuyendo la realización de las primeras instantáneas en territorio español al Dr. Santiago Ramón y Cajal y su socio, el fotógrafo Lucas Escolá, recientes estudios han dado a conocer el papel esencial del Dr. Ferrán Clúa en estas primeras experiencias fotográficas que tuvieron lugar en la ciudad de Zaragoza. Durante sus viajes a lo largo del territorio peninsular, los operarios de la compañía J. Lévy et Cie realizaron un importante acopio de materiales en los diferentes formatos (álbum, panorámico, estereoscópico, etc.), en torno a 10.000 placas, que se conservan en la actualidad en el fondo "Leon et Lévy" de la Agencia Roger-Viollet de París. Este ingente material fotográfico se constituye en el más fidedigno retrato colec-
\end{abstract}

\footnotetext{
* Este artículo se ha realizado en el marco del proyecto de investigación Arquitectura, Urbanismo y Representación en la construcción de la imagen de los barrios artísticos (Ref. HAR2012-38899C02-02). MINECO Convocatoria 2012. Plan Nacional I+D+i. Subprograma de Proyectos de Investigación Fundamental No Orientada.

** Miembro del grupo de investigación "Observatorio Aragonés de Arte en la Esfera Pública" financiado por el Gobierno de Aragón con fondos F.S.E.
} 
tivo posible de aquella España monumental e histórica, de sus ciudades y de sus gentes, capturado, a través de la mirada ajena, pero cómplice, de estos experimentados fotógrafos franceses. Como apéndice documental, a modo de inventario, culmina este estudio una relación numerada de las tres series de tarjetas postales estereoscópicas, editadas en torno a 1900-1905 por la casa Lévy \& ses files, a partir de los negativos originales tomados durante la segunda mitad de la década de 1880.

Palabras clave: Instantaneidad, estereoscopía, viajes fotográficos, España, Roger Viollet, J. Levy et Cie, Ramón y Cajal, Escolá, tarjetas postales.

\title{
Instantaneity and stereoscopy: the photographic journey through Spain of Parisian company J. Lévy et Cie., at late nineteenth century
}

\begin{abstract}
:
In the mid 1880s Parisian photographic company J. Lévy et Cie traveled along Spain over successive trips, practicing for the first time in a systematic way, the technique of the snapshot. That is, making use of modern emulsion gelatin silver bromide, discovered by Richard L. Maddox in 1871, and perfected with successive contributions (Kennet, 1874, Harper Bennett, 1878; Monckhoven, 1879). Although traditionally it have been attributed the realization of the first snapshots in Spanish territory to Dr. Santiago Ramón y Cajal and his partner, photographer Lucas Escolá, recent studies have revealed the essential role of Dr. Ferrán Clúa, in these early photographic experiences that took place in the city of Zaragoza. During his travels along the Spanish mainland, the operators of the company J. Lévy et Cie made an important collection of materials in various formats (album, panoramic, stereoscopic, etc..), around 10,000 plates, which are preserved today in the section "Leon et Levy" of Roger-Viollet Agency in Paris. This vast photographic material constitutes the most reliable possible collective portrait of that monumental and historical Spain, its cities and its people, captured through foreign, but accomplices, eyes of these experienced French photographers. As documentary appendix, for inventory, this study culminates with a numbered relationship of the three series of stereoscopic postcards, edited around 1900-1905 by Levy \& ses files company, from original negatives taken during the second half of the 1880 s.
\end{abstract}

Key words: Instantaneity, stereoscopy, photography trips, Spain, Roger Viollet, J. Levy et Cie, Ramon y Cajal, Lucas Escolá, postcards. 
Sumario: 1.- Introducción. 2..- Aquella España de la década de 1880. 3.- La agencia RogerViollet y el fondo Léon et Lévy. 4.- Los antecedentes: Ferrier et Soulier, 1863 - 1864. 5.Viajes por España de la firma J. Lévy et Cie, 1885 y 1888-1889. 6.- Breves apuntes sobre la fotografía estereoscópica. 7.- Acerca de la instantaneidad fotográfica en España. 8.- La edición de tarjetas postales, entre 1900 y 1915. 9.- Apéndice documental: España / L'Espagne (24), Andalucía / Andalousie (24), Norte de España / Nord de l'Espagne (24). 10.Referencias bibliográficas.

\section{Introducción ${ }^{1}$}

Cuando, a mediados de la década de 1880, la compañía J. Lévy et Cie decida llevar a cabo una campaña fotográfica a través del territorio peninsular, lo hará guiada fundamentalmente por dos motivaciones: de un lado, la necesidad de ampliar su repertorio de imágenes de España, heredado del antiguo gabinete de Ferrier, père, fils et Soulier, que no obstante seguirá comercializando todavía en su catálogo de 1904, y, de otro, la oportunidad de actualizar su mirada sobre la España de finales del siglo XIX (también sobre Portugal, Gibraltar y Marruecos), haciendo por primera vez uso de la moderna emulsión al gelatino-bromuro de plata. Es decir, de la técnica de la instantánea.

Su monumental repertorio de instantáneas españolas, cuya cifra se estima en torno a los 10.000 negativos, se custodia en la actualidad en los almacenes de la Agencia Roger-Viollet en París y permanece en su mayor parte inédito

\footnotetext{
${ }^{1}$ La presente ponencia nace con la intención de concederle mayor difusión al estudio de carácter general que dediqué a las instantáneas zaragozanas que la compañía J. Lévy tomó en 1889. Habida cuenta de que aquel estudio monográfico y catálogo de la exposición que comisarié en el Palacio de la Aljafería de las Cortes de Aragón en el verano de 2012 quedó reducido exclusivamente a su edición digital, a la espera de que mejores tiempos permitan acometer su edición impresa. Es por ello que actualizo aquí, en algunos casos, en otros añado y en otros transcribo en su integridad algunos de los contenidos que fueron presentados en el estudio previo de la citada edición, cuyo título íntegro indico en la sucesiva nota a pie de página. No quisiera concluir esta breve nota introductoria sin agradecer afectuosamente a mis colegas de la Universidad Complutense de Madrid, Pilar Aumente Rivas y Carlos Pérez Reyes, Directores de las V Jornadas de Arte y Ciudad (II Encuentros Internacionales), así como al profesor Miguel Ángel Chaves Martín, coordinador de las mismas, su invitación y su cordialidad.
} 
todavía ${ }^{2}$. Este importante conjunto de materiales fotográficos se constituye en un documento irreemplazable a la hora de evocar la imagen de aquella España, sus ciudades y sus habitantes, que se encaminaba hacia el final de siglo al ritmo de los, entonces rabiosamente modernos, tranvías de mulas.

A diferencia de otros repertorios fotográficos urbanos precedentes, realizados por fotógrafos foráneos como Charles Clifford (1819-1863) o Jean Laurent (1816-1886), entre otros, en los que contemplamos con frecuencia ciudades espectralmente deshabitadas, con sus calles y monumentos en soledad, consecuencia de la limitada fotosensibilidad del colodión húmedo, el ingente repertorio fotográfico realizado por los fotógrafos franceses de la firma J. Lévy et Cie, nos muestra, por primera vez, las ciudades animadas por la presencia de su contingente humano, en las que la vida en la calle recupera todo su protagonismo y espontaneidad.

El concienzudo y sistemático método de trabajo de los operarios de la compañía parisina, en el que incorporaron diferentes formatos comerciales (formato álbum, estereoscópico y panorámico), no tiene parangón con ninguna de las actuaciones precedentes, ni siquiera con las llevadas a cabo por las más importantes compañías fotográficas establecidas en nuestro país. Ya que, hasta entonces, debido a la exclusividad y carestía de los materiales fotográficos, lo habitual era que, en el mejor de los casos, el fotógrafo realizara, desde la localización elegida, imágenes en un único formato, o como máximo en dos formatos (estereoscópico y formato álbum), y realizara como mucho, dos tomas consecutivas en cada uno de esos formatos. Esa segunda toma, en realidad se tomaba por precaución y servía como copia de seguridad o de archivo, ante un posible deterioro de los frágiles negativos sobre vidrio, rotura, pérdida o problemas en el revelado posterior de las emulsiones, etc.

\footnotetext{
${ }^{2}$ Hasta el momento se han publicado tres estudios parciales sobre las instantáneas españolas conservadas en el fondo "Léon et Lévy" de la Agencia Roger-Viollet de París. Se trata de las siguientes monografías: Huguet Chanzá, José (1999): Valencia en 1888, Ayuntamiento de Valencia, Valencia; Garófano Sánchez, Rafael (2002): Andaluces y marroquíes en la colección fotográfica Lévy (1888-1889), Diputación de Cádiz, Cádiz y Hernández Latas, José Antonio (2012): Zaragoza en la mirada ajena. Instantáneas del archivo Roger-Viollet de Paris: J. Lévy et Cie, 1889, Cortes de Aragón, Zaragoza [edición digital].
} 

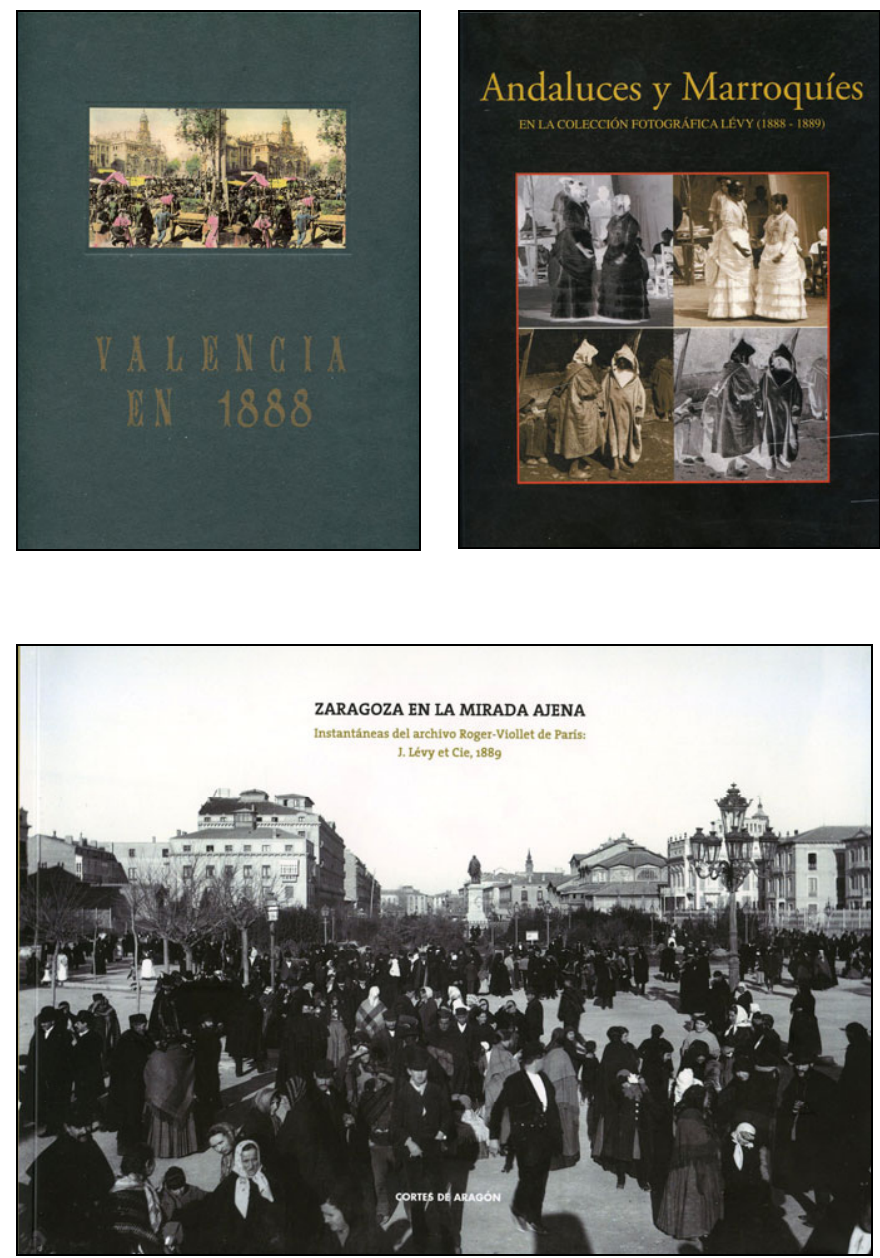

Sin embargo, como venimos diciendo, el modus operandi llevado a cabo por los fotógrafos de la compañía J. Lévy et Cie, no tiene precedentes en nuestro territorio. Su elemento diferencial lo constituye el despliegue de medios llevado a cabo para cada una de las localizaciones seleccionadas. Esto es, se disponían, al menos, tres cámaras fotográficas, asentadas sobre sus correspondientes trípodes, que generaban hasta cuatro tipos de formatos fotográficos (formato álbum -24 x $30 \mathrm{~cm}-$, panorámico $-13 \times 21 \mathrm{~cm}-$, y dos tipos de formatos estereoscópicos distintos - $10 \times 21$ y $13 \times 21 \mathrm{~cm}$-). Pero, no solo eso, en cada uno de dichos formatos se tomaba un mínimo de dos negativos, $\mathrm{y}$ en ocasiones, tres, cuatro y hasta cinco. 
Visto con la perspectiva del tiempo, lo interesante y no suficientemente ponderado de dicha metodología de trabajo es que generaba un ingente material, con tomas sucesivas y sutilmente diferentes, siempre únicas. Hasta el punto de que, una vez digitalizadas y proyectadas sucesivamente las imágenes generadas, podemos obtener experiencias de tipo precinematográfico a partir de su visualización. Dicho de otro modo, las instantáneas obtenidas nos permiten disponer de escenarios urbanos en los que asomarnos con la mayor veracidad al ritmo, siempre cambiante, de la vida ciudadana de aquella España de hace más de un siglo.

Esta estrategia empresarial, todo un compromiso sensorial con la realidad, les obligó a realizar una fuerte inversión en materiales que, sin embargo, distó mucho de resultar rentable, ya que la culminación del viaje peninsular de la firma J. Lévy vino a coincidir prácticamente con el nacimiento en España de la tarjeta postal ilustrada, en la década de 1890, que experimentó un desarrollo vertiginoso y que pronto desbancaría los formatos y materiales fotográficos tradicionalmente comercializados. Como es bien sabido, la evolución y perfeccionamiento industrial de las artes fotomecánicas puso fin a los límites en la reproducción de ejemplares fotográficos y abarató sustancialmente el precio de las imágenes resultantes. Estamos ante el inicio de una nueva era y el nacimiento de una moda, la cartofilia, que alcanzó a todas las capas de la sociedad.

Aunque un cierto número álbumes fotográficos se llegaron a comercializar, a juzgar por las series de albúminas que vamos recuperando y también de vistas estereoscópicas sobre vidrio y papel, lo cierto es que el grueso de la colección de fotografías españolas de la firma J. Lévy et Cie permaneció inédito en los almacenes de la compañía y sin posibilidad de encontrarle una salida comercial. Por lo que, siguiendo el ejemplo de otras empresas fotográficas coetáneas, una década más tarde, hacia 1900, la firma parisina decidió adaptarse a los nuevos tiempos y reconducir su estrategia editorial. Así pues, finalmente estampó y comercializó, mediante la técnica de la fototipia, diferentes y sucesivas ediciones de tarjetas postales a partir de los negativos originales tomados en España a finales de la década de 1880. Se trata de las series, Espagne, Nord de l'Espagne, Andalousie y B.P., que se constituyen en un valioso testimonio acerca de la mirada cómplice de aquellos laboriosos fotógrafos franceses sobre nuestro país y sus habitantes. 


\section{Aquella España de la década de $\mathbf{1 8 8 0 .}$}

Desde la restauración borbónica, España vivía por fin un período de estabilidad política, que había dejado atrás las constantes amenazas y asonadas carlistas y que estaba basado en el llamado sistema de turno o alternancia política de los dos principales partidos políticos, los conservadores de Cánovas y los liberales de Sagasta. Ni que decir tiene que dicha estabilidad política nacía lastrada por la generalización de la corrupción y el fraude electoral. Ambos consecuencia del ancestral poder que en el ámbito rural ejercían los caciques locales, como denunciaría años más tarde Joaquín Costa en su informe Oligarquía y Caciquismo como forma de gobierno en España (Ateneo de Madrid, 1901).

Sería, sin embargo, el de 1885 un fin de año convulso, especialmente por la incertidumbre política que provocó el inesperado fallecimiento de Alfonso XII, víctima como su primera esposa, María de las Mercedes, de la enfermedad de la tuberculosis. De nuevo las aspiraciones de carlistas, republicanos e incluso de los partidarios del retorno de la madre de Alfonso XII, Isabel II, amenazaban la estabilidad política conseguida. Pero será, una vez más, el acuerdo entre los dos grandes partidos, liberales y conservadores, el que garantice la continuidad del sistema monárquico, mediante el llamado "Pacto de El Pardo", con la proclamación de la Regencia de María Cristina de Habsburgo, viuda del monarca, entonces embarazada del futuro Alfonso XIII.

No podemos tampoco pasar por alto la virulencia que en ese mismo año de 1885 alcanzó la epidemia de cólera morbo asiático, que asoló España. Y que, a pesar de los esfuerzos de las autoridades sanitarias y de las diferentes iniciativas profilácticas puestas en marcha en diferentes provincias, su mortandad superó la terrible cifra de 120.000 fallecidos.

Eran, además, los tiempos de la Gran Depresión de la economía europea, que tuvieron una especial incidencia en España en asuntos como la llamada "cuestión agraria". Y es que la economía de nuestro país, cuyo crecimiento estaba basado fundamentalmente en el desarrollo del sector primario, se vio afectada por la caída de los precios de los productos agrícolas, consecuencia de la fuerte competencia que ejercían los productos importados desde el otro lado del Atlántico. En muchos territorios del interior peninsular, debido a la escasa o nula rentabilidad de los cultivos, muchos pequeños propietarios y arrendatarios llegaron incluso a abandonar sus explotaciones, en busca de mejores oportunidades en las ciuda- 
des, especialmente en los entornos industriales de Bilbao y Barcelona. Pero también, recalando en otras ciudades no industrializadas, con la intención de copar los escasos puestos de trabajo que pudiera proporcionarles el sector de los servicios. Por ello, no es extraño que en este periodo sea frecuente encontrar en la prensa noticias sobre el aumento del contingentes de desempleados que se concentran habitualmente en las principales plazas públicas de ciudades como Zaragoza o Valencia, a la espera de cualquier tipo de oferta laboral. Pero la peor consecuencia de este éxodo rural tuvo su reflejo en el importante aumento de la mendicidad en las calles, en ocasiones ejercidas por familias enteras, como constatan con insistencia las gacetillas de la prensa local.

Pero, por fortuna, también el final de la década de 1880 contempló un acontecimiento que insufló cierto optimismo a la sociedad española y que marcó social y culturalmente de un modo exitoso el final de la década; este fue la Exposición Universal de Barcelona 1888. Con el apoyo y la complicidad de la reina regente y del gobierno de Mateo Práxedes Sagasta, y auspiciada por la boyante burguesía industrial catalana, la de Barcelona fue la primera exposición de carácter universal celebrada en España, y sería visitada por más de dos millones de personas. El Parque de la Ciudadela fue el espacio que acogió el ambicioso proyecto del alcalde Ríus i Taulet y que supuso entre otros beneficios para la ciudad, la incorporación del Modernismo arquitectónico como una de sus futuras señas de identidad.

\section{La agencia Roger-Viollet y el fondo Léon et Lévy.}

La historia de la agencia fotográfica Roger-Viollet, una de las más antiguas de Francia, se remonta hasta el año 1938, en que fue fundada bajo la denominación Documentation Photographique Générale Roger-Viollet por Hélène RogerViollet y su marido Jean-Víctor Fischer, en un local comercial de rue de Seine, 6, de París, sobre la base inicial de los fondos fotográficos constituidos por Henry Roger-Viollet, padre de Hélène, veterano fotógrafo e ingeniero.

Hélène Roger-Viollet había sido una de las primeras fotoperiodistas en cubrir la Guerra Civil española, junto a su marido Jean Fischer. Después de la II Guerra Mundial, el matrimonio comienza a enriquecer el legado fotográfico familiar de la agencia con continuas adquisiciones. Como la propia publicidad de la agencia informa, con el tiempo lograron construir una colección 
única en Europa, que cubre más de siglo y medio de la historia universal, de la historia de Francia y específicamente de la ciudad de París. Su organización se estructura fundamentalmente en torno a cuatro temas: principales acontecimientos históricos, París, retratos de personalidades y reproducciones de obras de arte. En 1985, tras la muerte de sus fundadores, su monumental archivo, compuesto por cerca de cuatro millones de negativos y más de dos millones de positivos, fue legado al Ayuntamiento de París. Y, desde el año 2005, la agencia Roger-Viollet se integra en Parisienne de Photographie, sociedad público-privada encargada de la digitalización, difusión y comercialización de las colecciones iconográficas del Ayuntamiento de París, sus museos y bibliotecas.

Dentro de los fondos fotográficos custodiados por la agencia Roger-Viollet, encontramos el fondo que nos ocupa, clasificado como Léon et Lévy, que fue adquirido por la agencia en el año 1970.

En 1864, Moyse Léon e Isaac Levy, dicho George (1833 - 1913), fundan la firma Léon et Lévy [L. L.], tras adquirir los importantes fondos fotográficos del gabinete parisino de Ferrier, père, fils et Soulier, del que habían sido operarios y que tenía su sede en el boulevard Sébastopol, 113. En 1867 la nueva firma se da a conocer internacionalmente gracias a haber obtenido la concesión para realizar las vistas estereoscópicas de la Exposición Universal de París, cuyo trabajo es galardonado además con la Gran Medalla de Oro del Emperador. A partir de entonces, la casa Léon et Lévy desarrolló una intensa actividad fotográfica, viajera y editorial, que puede seguirse a partir del estudio de sus catálogos generales, editados en 1870, 1886 y 1903, así como en el específico dedicado a España, Portugal y Marruecos editado en 1904, del mayor interés para el trabajo que nos ocupa.

A partir de 1872, Moyse Léon desaparece de la firma e Isaac Lévy pasa a dirigir la compañía, ahora bajo la denominación J. Lévy et Cie. Existe una cierta discordancia entre las siglas de la empresa y el nombre propio del propietario, como habrán tenido ocasión de constatar y que ha generado ciertas divergencias en su utilización por parte de los historiadores. Algunos investigadores vienen identificando al propietario de la firma J. Lévy como Jules Lévy. Sin embargo, mientras no sean publicados nuevos documentos que lo desmientan, debemos mantener la identificación más precisa, publicada por la historiadora Elizabeth Anne MacCauley (1994: 392), quien transcribe su 
nombre como Isaac George Levy, tras haberlo encontrado citado expresamente como fotógrafo censado en el boulevard Sébastopol, 113, en un documento fechado en 1871. Se hacen también eco de esta interpretación el desaparecido John B. Cameron (2007: 850-852) y, más recientemente, Juan A. Fernández Rivero (2011: 105) y Michel Mégnin (2008), entre otros solventes investigadores.

Consecuencia de su estrategia de expansión comercial, además de enviar a sus operarios en diferentes viajes por América (1869), el Canal de Suez (1870), Europa y California (1874), la firma J. Lévy et Cie sería galardonada sucesivamente con medallas de oro por su participación en las exposiciones de Bruselas (1880), Burdeos (1882) y Amsterdan (1883). Tuvo igualmente una destacada participación en la Exposición Internacional de las Ciencias y las Artes Industriales de París de 1887, fecha a partir de la cual emprenderá una importante campaña fotográfica por Europa, pero en este caso, a diferencia de sus anteriores series, haciendo uso de la moderna técnica de la instantánea, sobre la que tendré ocasión de extenderme más adelante.

Durante la segunda mitad de la década de 1880, con motivo de la Exposición Universal de Barcelona y aprovechando la consolidación y expansión de la red ferroviaria nacional, los fotógrafos de la firma francesa J. Lévy et Cie realizaron un exhaustivo recorrido por la Península, que les llevaría a visitar y fotografiar las principales ciudades de España.

Paulatinamente los hijos de Isaac Lévy, Abraham Lucien y Gaspard Ernest, irán cobrando mayor protagonismo en la compañía y como consecuencia, el año 1895, tiene lugar un nuevo cambio en la denominación comercial de la firma, pasando a registrarse como Lévy fils et Cie y también Léry \& ses fils. Desde comienzos del siglo XX la empresa fotográfica reconducirá su actividad hacia la edición de tarjetas postales, registrando a este efecto sus conocidas siglas "L.L." ya en el año 1901. A partir de entonces la empresa editorial experimentó tal auge que, según consta en su información publicitaria de 1913, ese año llegó a emplear nada menos que a 600 operarios y su producción de tarjetas postales superó la exorbitante cifra de 107 millones de ejemplares. Poco después, hacia 1920, Lévy $\mathcal{E}$ ses fils estableció sociedad con la editorial Neurdein Frères y constituyeron la firma Lévy \& Neurdein Réunis que, desde 1932, se reconvertirá en Compagnie des Arts Photomecániques [C.A.P.]. A partir de 1970, como hemos indicado, sus fondos fotográficos fueron adquiridos por la agencia Roger-Viollet. 


\section{Los antecedentes: Ferrier et Soulier, 1863 - 1864.}

Ya hemos advertido que la firma J. Léry et Cie remonta sus orígenes hasta el legado fotográfico de Ferrier, père, fils et Soulier. Claude Marie Ferrier (1811-1889), presente ya como fotógrafo en la Exposición Universal de Londres de 1851, había comenzado su carrera realizando daguerrotipos estereoscópicos para Jules Dubosq. Por su parte, Charles Soulier (1834-1876) en 1854 había establecido sociedad en París con Athanase Clouzard, con el objeto de elaborar pruebas estereoscópicas sobre cristal. Pero tras acusar Soulier a su socio, Clouzard, de competencia desleal, quedó disuelta la sociedad en el año 1859. A partir de esa fecha, Soulier vendió la parte de la sociedad perteneciente a Clouzard a Claude Marie Ferrier y al hijo de éste, Jacques-Alexandre Ferrier (1831-1912), estableciendo la nueva sociedad denominada Ferrier, père, fils et Soulier, que se mantendría en activo con dicha denominación hasta el año 1864, en que, como hemos relatado, sería adquirida por dos de sus empleados, Moyse Léon e Isaac George Lévy.

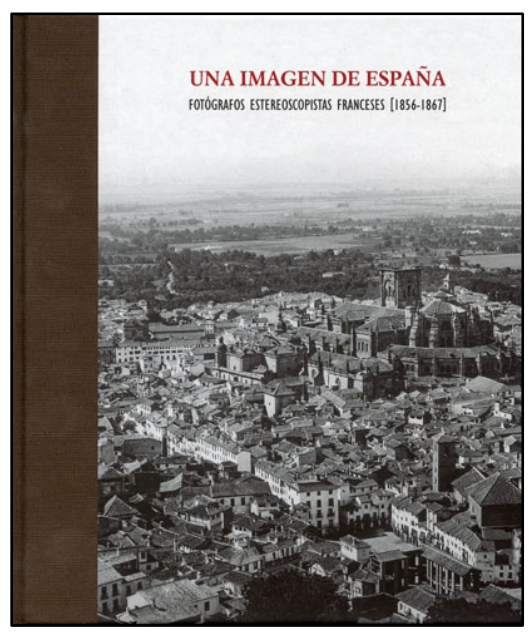

Fig. 4. Portada del libro Una imagen de España. Fotógrafos estereoscopistas franceses [1856-1867], VVAA (Madrid, 2011)

Recientemente, en noviembre del año 2011, ha tenido lugar con el título Una imagen de España. Fotógrafos estereoscopistas franceses [1856 - 1867], una exposición y, sobre todo, la edición de una publicación que cabe calificar de ejemplar. Ella ha sido el fruto de la pasión por el coleccionismo y la historia de la fotografía en España de un conjunto de especialistas bien avenidos, que han aparcado sus intereses personales y han puesto en común sus investigaciones, una bibliografía más que exclusiva, nuevas aportaciones documentales y sus colecciones inéditas, para construir entre todos ellos una visión panorámica acerca de la presencia de los fotógrafos estereoscopistas franceses en nuestro país durante las décadas de 1850 y 1860, es decir, en los tiempos en que el colodión húmedo era la emulsión fotográfica hegemónica. El resultado de ese esfuerzo compartido ha sido un admirable trabajo de investigación, que desde su aparición se ha constituido en una 
obra de referencia. El estudio pormenorizado de las series de vistas estereoscópicas y colecciones realizadas o editadas respectivamente por Joseph Carpentier, Ferrier et Soulier, Gaudin Fréres, Ernest Lamy o Jean Andrieu, ilustran con precisión el interés tardo romántico de estos pioneros de la fotografía francesa por la España monumental e histórica.

Indiscutiblemente, Andalucía y, en menor medida, los antiguos territorios de Castilla fueron durante esos años las regiones que más unánimemente concitaron el interés de los primeros estereoscopistas franceses. A este respecto, resulta harto elocuente el cuadro comparativo elaborado por Rafael Garófano, en el que coteja cuantitativamente el contenido de todos los catálogos y colecciones de cada uno los fotógrafos citados.

Precisamente el citado Catalogue des Épreuves Stéréoscopiques sur verre et vues pour la projection. Espagne, Portugal, Maroc, photographiés et publiés par Levy $\mathcal{E}$ ses fils, editado en Paris en 1904, se inicia con las series de fotografías estereoscópicas sobre vidrio, al colodión húmedo, que se corresponden con dos viajes sucesivos a España promovidos por la firma Ferrier, père, fils et Soulier en los años 1857 y 1863-1864, respectivamente. Ambos viajes agrupados ahora en uno solo bajo el epígrafe Voyages en Espagne, combinaba, ciudad a ciudad, las vistas estereoscópicas realizadas en esos dos viajes sucesivos, aunque manteniendo sus numeraciones originales (series 6000 y 7000, respectivamente). Pero en esta última edición ya no figuran, seguramente debido a su deterioro, algunas de las vistas estereoscópicas que sí recogen los catálogos editados por Ferrier, père, fils et Soulier (1864) y por M. Léon et J. Lévy (1870). En cualquier caso, siguiendo las relaciones de estos dos últimos catálogos, podemos reconstruir íntegramente el itinerario de ambos viajes:

- Viaje a España, datado en 18573: Números 6401 a 6515. Con un total de 116 imágenes de las poblaciones de Madrid, La Granja, Segovia, Toledo, Cuenca, Córdoba, Sevilla, Granada, Málaga, Ronda y Gibraltar.

\footnotetext{
${ }^{3}$ Como relata Carlos Sánchez Gómez (2011) en su epígrafe "Controversias e hipótesis sobre la autoría de las imágenes editadas por Ferrier y Gaudin", la aparición de las inscripciones "C.S." en el ángulo de algunas de las vistas estereoscópicas sobre vidrio, realizadas durante ese primer viaje datado en 1857, llevaron a algunos investigadores a proponer la autoría para las mismas de
} 
- Viaje a España, datado en torno a 1863 - 1864: Números 7025 a 7182, más tres vistas con la indicación "bis". Con un total de 161 imágenes de las poblaciones de Pamplona, Olite, Zaragoza, Montserrat, Barcelona, Murviedro, Valencia, Alicante, Cartagena, Málaga, Granada, Cádiz, Toledo, Aranjuez, Madrid, La Granja, El Escorial, Burgos y Gibraltar.

Como ya hemos dicho en otras ocasiones, a pesar de que estas imágenes fueran tomadas en torno a 1863-1864, su comercialización se prolongó en el tiempo, como dan muestra su presencia todavía en el catálogo de 1904, o por poner un ejemplo concreto, la inscripción manuscrita conservada en el reverso de la tarjeta estereoscópica de la colección Arguas, no 7037, que transcribo a continuación: Puente sobre el Ebro y Ntra. / Sra. del Pilar en Zaragoza / La Habana, $24-12$ - 83, y que debió ser adquirida o remitida desde Cuba en 1883.

\section{Viajes por España de la firma J. Lévy et Cie, 1885 y 1888-1889.}

Ante la imposibilidad física de manejarse con los miles de negativos fotográficos que custodia el fondo León et Levy de la agencia Roger-Viollet, la fuente esencial que nos permitirá reconstruir el itinerario de los fotógrafos de la firma J. Lévy et Cie por España es el Catalogue des Épreuves Stéréoscopiques sur verre et vues pour la projection. Espagne, Portugal, Maroc, photographiés et publiés par Levy $\mathcal{E}$ ses fils, editado en Paris en 1904, al que nos venimos refiriendo.

Dejando a un lado los primeros viajes, realizados por la casa Ferrier, père, fils et Soulier, de los años 1857 y 1863-1864, ya analizados, y que en el citado catálogo aparecen recogidos ambos, con toda propiedad, bajo la denominación Voyages en Espagne, las páginas de la publicación comercial francesa estructuran lo que consideramos fueron varias estancias consecutivas de los operarios franceses en España durante la década de 1880. Pues bien, junto a esos primeros Voyages en Espagne (págs. 3 a 13) y dejando al margen los últi-

Charles Soulier, o incluso de Clouzard y Soulier. Sin embargo, el reciente hallazgo de una carta de Charles Clifford a la Societé Française de Photographie, con fecha de 8 de junio de 1857, en la que comunica que se encuentra realizando pruebas estereoscópicas en Segovia para la firma Ferrier et Soulier, permite atribuirle la autoría de las imágenes de este primer viaje de 1857. No así las del segundo, ya que Clifford, como es sabido, falleció el 1 de enero 1863. 
mos apartados dedicados a Portugal y Marruecos, la publicación se estructura en las siguientes partes, que analizaremos con detenimiento:

- (págs. 14 a 27) Nouveau voyage en Espagne: Córdoba, Granada (Alhambra, Generalife), Sevilla (Alcázar, Casa de Pilatos, Catedral, Procesiones, Vistas exteriores, Palacio de San Telmo, Iglesias, Casas particulares, vistas diversas, Exteriores de Sevilla, Corridas de Toros), Cádiz, San Sebastián, Fuenterrabía, Pasajes, Hernani, Irún.

- [1888 / 1889] (págs. 28 a 57) Nouveau voyage en Espagne: Barcelona (Exposición Universal de 1888), Montserrat, Toledo, Burgos, Ávila, Valladolid, Segovia, La Granja, Madrid, El Escorial, Palacio del Escorial, Casino del Príncipe, Valencia (Le Camposanto, Le jour de la toussaint), Murviedro, Tarragone, Zaragoza / Gibraltar / Archena (Murcia), Murcia (Procesión de Semana Santa), Játiva, Lorca, Elche, Alicante, Cartagena, Loyola, Azpeitia.

- (pág. 58) Complement au Voyage en Espagne: San Sebastián.

- (págs. 59 a 60) Voyage aux Iles Baleares.

Como vemos, los viajes realizados en la década de 1880 a España ya por los fotógrafos de la firma J. Léry et Cie, se articulan fundamentalmente en dos viajes o estancias, que se complementarán, a su vez, con otros dos viajes puntuales a la ciudad de San Sebastián, por un lado, y a las islas Baleares, por otro. La estructura presentada en esta relación de ciudades españolas visitadas no es fortuita, sino que obedece escrupulosamente a dos viajes a España, consecutivos, pero distantes en el tiempo.

Según han investigado recientemente Carlos Sánchez Gómez y Rafael Garófano, las fotografías andaluzas del primero de los Nouveau voyage en Espagne, no fueron realizadas, como se creía hasta ahora, en 1888. Sino que corresponderían a un viaje previo, realizado en 1885 , como vienen a constatar las imágenes sobre el estado de las obras de restauración acometidas en la Alhambra bajo la dirección de Rafael Contreras Muñoz, decorador adornista de las obras de dicho monumento entre 1851 y 1889. Entre dichas imágenes, una fotografía de la visita de la embajada marroquí a la Alhambra, recientemente publicada (Sánchez Gómez, 2012), permite establecer todavía con mayor precisión la datación de la estancia de los fotógrafos de la casa J. Lévy, ya que por las rúbricas conservadas en el libro de visitas del monumento conocemos la datación exacta de 
la visita, que tuvo lugar en diciembre de 1885. Abundando en este razonamiento, parece lógico suponer que el resto de ciudades no andaluzas, agrupadas dentro de ese primer Nouveau voyage en Espagne, también fueron fotografiadas en torno a 1885, pero es algo que está pendiente de comprobación.

Fig. 5.

Embajada marroquí en el Patio de los Leones de la Alhambra.

J. Lévy et Cie, diciembre 1885. [Cortesía de Carlos Sánchez Gómez]

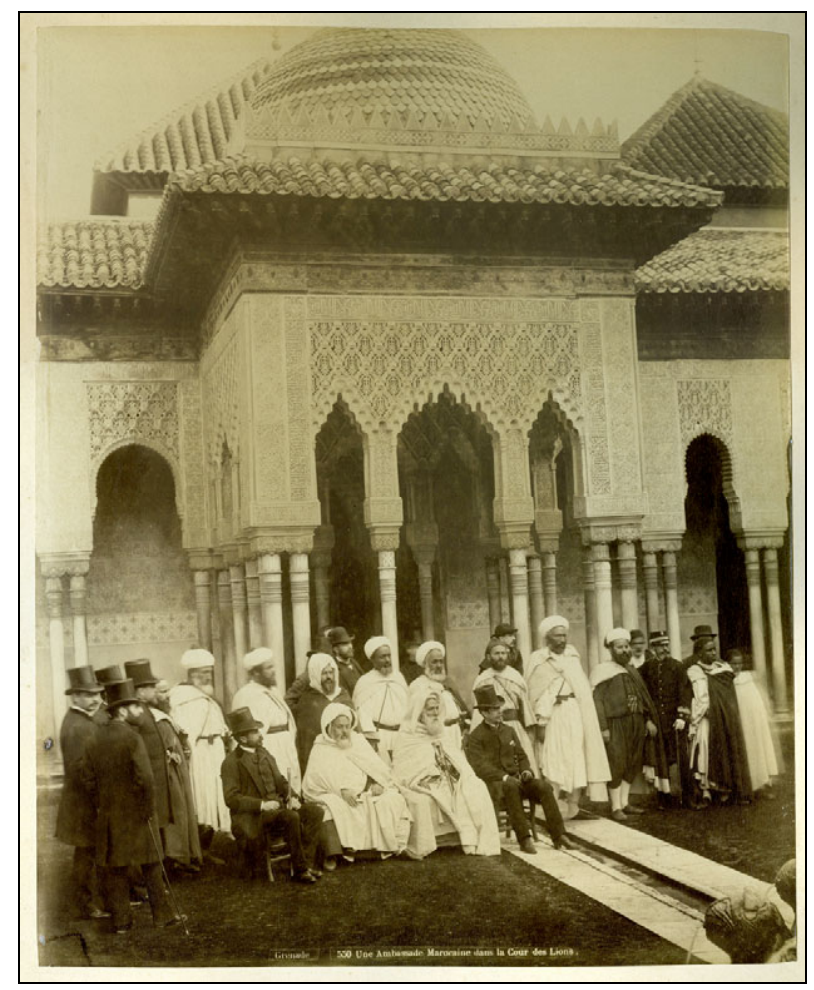

Lo que parece indiscutible es que el segundo de los nuevos viajes fue realizado durante los años 1888 y 1889, seguramente en respuesta al reclamo de los fastos de la Exposición Universal de Barcelona de 1888, de la que se recogen en el amplio repertorio fotográfico diferentes instantáneas del recinto de la Exposición Universal, también de la inauguración del Monumento a Colón (1 de junio de 1888), etc. Algunos otros hitos iconográficos que nos permiten cimentar la cronología de este segundo viaje serían la concurrida afluencia ciudadana al Camposanto de Valencia en el día de Todos los Santos (1 de noviembre de 1888), los carteles callejeros alusivos a las festividades del Carnaval en la ciudad de Zaragoza, durante los meses de febrero y marzo de 1889, o las procesiones de Semana Santa celebradas en Murcia (14 a 21 de abril de 1889). 


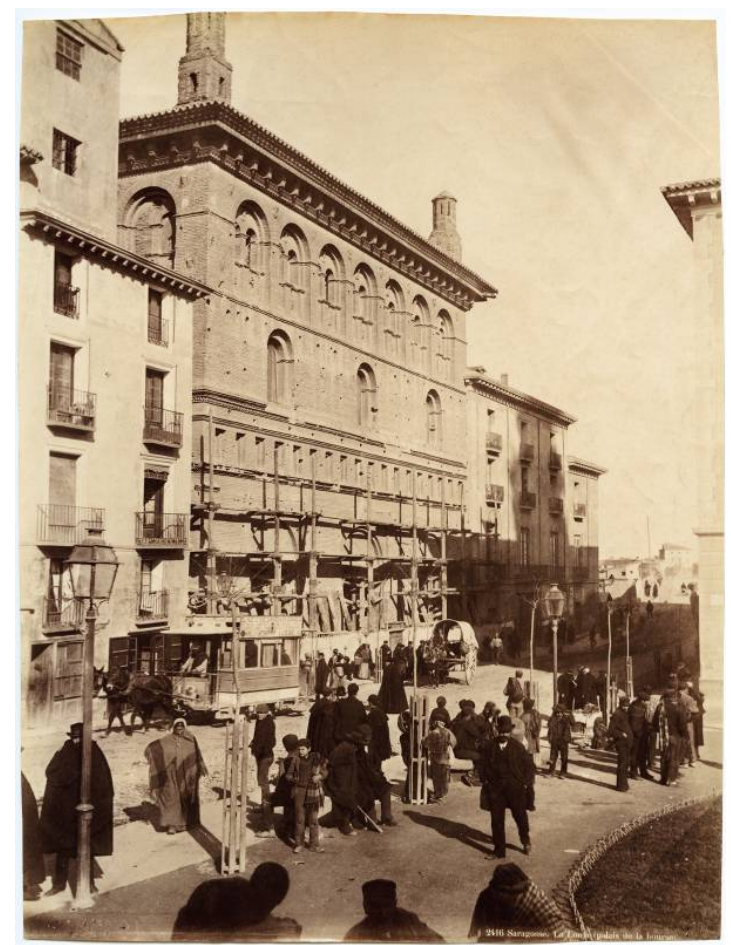

Fig. 6. № 2416. Zaragoza. La Lonja. J. Lévy et Cie, 1889. Cortesía Fco. Monzón Alebesque.

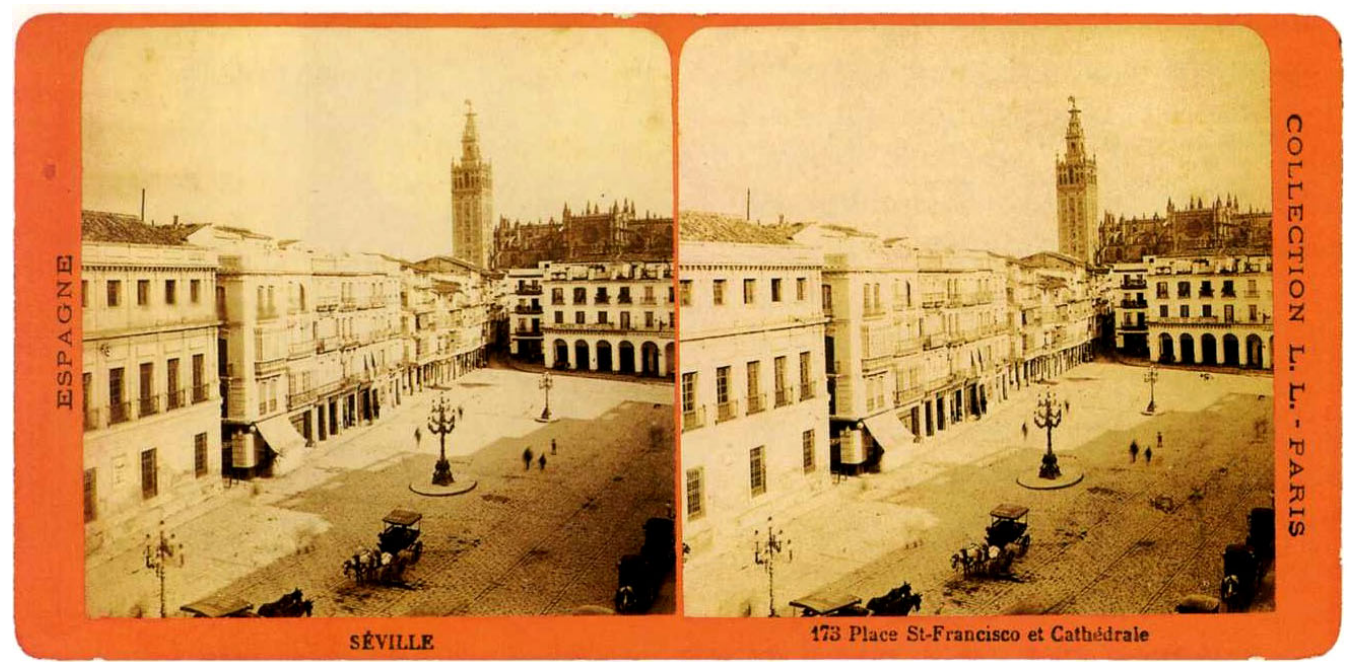

Fig. 7. № 173. Sevilla. Plaza de San Francisco y Catedral. J. Lévy et Cie, 1885 Rafael Garófano (Andaluces y marroquíes..., Cádiz, 2002). 


\section{Breves apuntes sobre la fotografía estereoscópica.}

Como hemos tenido ocasión de adelantar, entre los diferentes formatos abordados por los fotógrafos parisinos encontramos hasta dos tipos de formatos estereoscópicos (10 x 21 y $13 \times 21 \mathrm{~cm}$, respectivamente). Para quienes no estén familiarizados con la estereoscopía, adelantaré que el procedimiento técnico de la fotografía estereoscópica consiste, en esencia, en reproducir los mecanismos de la visión binocular humana, bien conocidos ya desde la Antigüedad y especialmente a partir del Renacimiento, que permiten obtener una percepción tridimensional de nuestro entorno. Para dicha percepción en relieve y en profundidad, el ser humano visualiza imágenes ligeramente diferentes a través de cada una de sus retinas, en razón de su distancia interocular, de aproximadamente 6,5 cms. Ambas imágenes se sintetizan en el cerebro componiendo una imagen única y tridimensional mediante el fenómeno físico conocido como "persistencia retiniana", que formulara el belga J.A.F. Plateau en 1829 y que consiste básicamente en la continuidad o memoria de la percepción registrada por la retina después de cesar el estímulo que la ha provocado (por un tiempo de 0,1 segundos, aproximadamente). Dicho fenómeno de la persistencia retiniana será la base de la ilusión de tridimensionalidad que proporciona la fotografía estereoscópica, pero también de la ilusión de movimiento a partir de la visualización, sin solución de continuidad, de una sucesión de imágenes fijas o fotogramas, que culminará en el cinematógrafo.

En 1838, un año antes de la presentación pública del daguerrotipo, el físico sir Charles Wheastone presentó ante la Real Sociedad de Londres el estereoscopio o "estereóscopo", un artilugio todavía de carácter experimental y de difícil comercialización, que permitía mediante la reflexión especular la percepción de tridimensionalidad a partir de unos dibujos geométricos, para posteriormente utilizar fotografías (calotipos). Pero será a sir David Brewster a quien debamos la realización de los primeros daguerrotipos estereoscópicos, mediante el ingenioso y sencillo procedimiento consistente en tomar dos imágenes sucesivas, con una cámara de un único objetivo, deslizándola sobre una guía marcada con la distancia interocular. Poco tiempo después, en 1849, el propio Brewster diseñó una cámara binocular o de doble objetivo, para daguerrotipos. Y para su posterior visualización, ideó y patentó un estereoscopio mucho más práctico y manejable que el de Wheastone, conocido con el nombre de marca de su creador, "Estereoscopio Brewster", que hará fortuna especialmente a par- 
tir de su presentación pública en la Exposición Universal de Londres de 1851. Desde estos primeros tiempos de la fotografía estereoscópica y hasta nuestros días, se contabilizan en centenares las patentes de visores estereoscópicos ${ }^{4}$, así como de cámaras fotográficas estereoscópicas comercializadas. Entre los primeros debemos citar el modelo de estereoscopio patentado por "Holmes \& Bates" hacia 1870, que con mínimas variantes fue sin duda el visor estereoscópico más imitado y comercializado hasta bien entrado el siglo XX.

\section{Acerca de la instantaneidad fotográfica en España.}

A diferencia de los repertorios fotográficos urbanos precedentes, en los que contemplamos una ciudad deshabitada, con sus calles y monumentos en soledad, consecuencia de la limitada fotosensibilidad del colodión húmedo, el repertorio fotográfico realizado por los fotógrafos franceses de la firma J. Lévy et Cie, durante sus diferentes viajes a la península nos muestra por primera vez una ciudad animada por la presencia de sus habitantes, en la que la vida en la calle recobra su protagonismo gracias a las modernas y mucho más sensibles placas secas al gelatino-bromuro, es decir, a la fotografía instantánea.

Técnicamente se califica de instantánea una fotografía cuya fotosensibilidad permite realizar tomas con una exposición temporal inferior a un segundo. El origen de la instantánea hay que buscarlo en la evolución y perfeccionamiento de la emulsión al gelatino-bromuro de plata, que dio a conocer el médico inglés Richard L. Maddox en 1871, basándose en los trabajos de Poitevin sobre la gelatina como sustrato seco (1851) y en las propiedades del bromuro como materia sensible (1853), estudiadas por Gaudin. Esta nueva emulsión, fue evolucionada por Richard Kennet en 1874 y perfeccionada por Harper Bennet en 1878, quien consiguió mejorar la fotosensibilidad de la emulsión hasta el punto de obtener tomas con una exposición temporal de tan solo 1/25 de segundo. Por último, ya en 1879, el químico belga Desiré Charles Monckhoven, consiguió aumentar sustancialmente su fotosensibilidad gracias a la adición de amoníaco en el periodo de maduración de la emulsión.

\footnotetext{
${ }^{4}$ Para la consulta y datación de los diferentes modelos y patentes de estereoscopios o visores estereoscópicos, resulta imprescindible acudir a la consulta del libro de Paul Wing (1996).
} 
La inmediata comercialización industrial de las nuevas placas secas o previamente preparadas al gelatino-bromuro, supondría toda una revolución. Si antes el fotógrafo no solo debía tener conocimientos en química, sino que además debía preparar una a una las placas al colodión húmedo y realizar la toma con la emulsión todavía fresca, goteando literalmente, a partir de ahora, cualquier aficionado, sin necesidad de tener conocimientos ni práctica en la elaboración de emulsiones fotosensibles, podía adquirir sus placas secas y tras realizar sus correspondientes tomas, dejarlas a revelar en cualquier laboratorio profesional. Aunque el inicio comercial de este tipo de placas en serie surgió hacia 1874 en Inglaterra, con la empresa Liverpool Dry Plates \& Co., su comercialización industrial vio su verdadero desarrollo a partir de la década de 1880, con empresas de la talla de Lumière, Braun y Garcin en Francia, Samuel Fry en Gran Bretaña o George Eastman en los Estados Unidos.

Como es sabido, Zaragoza fue la ciudad que acogió las primeras experiencias en España al respecto de la nueva emulsión al gelatino-bromuro, y que fueron debidas al Dr. Santiago Ramón y Cajal, en colaboración con el fotógrafo local Lucas Escolá Arimany (Sarriá, 1857 - Zaragoza, 1930)ํ. Nos referimos concretamente a unas instantáneas tomadas durante una corrida de toros de Beneficencia en la plaza de Zaragoza a comienzos de la década de 1880, que desgraciadamente no se han conservado:

Desconocíanse por aquella época en España las placas ultrarrápidas al gelatinobromuro, fabricadas a la sazón por la casa Monckhoven, y que costaban, por cierto, sumamente caras. Había yo leído en un libro moderno la fórmula de la emulsión argéntica sensible, y me propuse elaborarla para satisfacer mis aficiones a la fotografía instantánea, empresa inabordable con el engorroso proceder del colodión húmedo. Tuve la suerte de afinar pronto con las manipulaciones esenciales y aún de mejorar la fórmula de la emulsión; y mis afortunadas instantáneas de lances del toreo, y singularmente una tomada del palco presidencial, cuajado de hermosas señoritas (tratábase de una corrida de Beneficencia, patrocinada y presidida por la aristocracia aragonesa), hicieron furor, corriendo por los estudios fotográficos y alborotando a los aficionados. (Ramón y Cajal, 1901).

\footnotetext{
${ }^{5}$ Sobre el fotógrafo Lucas Escolá, ver el trabajo de SERRANO PARDO, Luis (2001), pp. 5-16.
} 
Durante un tiempo, Ramón y Cajal, con la colaboración de su mujer y del fotógrafo Lucas Escolá, se dedicó a la fabricación artesanal de placas al gelatinobromuro para satisfacer la creciente demanda de fotógrafos aficionados y profesionales locales, que comercializaba, junto a su socio, en la droguería de Jordán.

Más tarde, casado ya, llevé mi culto por el arte fotográfico hasta convertirme en fabricante de placas al gelatino-bromuro y me pasaba las noches en un granero, vaciando emulsiones sensibles, entre rojos fulgores de la linterna y ante el asombro de la vecindad curiosa, que me tomaba por duende o nigromántico.

Pero a este relato de los inicios de la práctica de la instantánea en España le faltaban algunas importantes claves, que han desvelado recientemente y de un modo brillante las investigaciones de Salvado Tió i Sauleda (2007). En 1879, el Dr. Jaime Ferrán Clúa (Corbera de Ebro, Tarragona, 1851 - Barcelona, 1929) y su colaborador Inocente Paulí y Galcerán (Tortosa, 1854 - Barcelona, 1921) publican el libro Instantaneidad en Fotografía. Algún otro historiador (Márquez, 2004) ya había apuntado la posibilidad de que fuera ese precisamente el "libro moderno" del que Ramón y Cajal pudiera aprender la fórmula de la emulsión al gelatino-bromuro. Ahora, los datos que ofrece Tió i Sauleda, no solo confirman esta hipótesis, sino que despejan cualquier tipo de duda al respecto.

Tirando del hilo de una entrevista realizada en Heraldo de Aragón a Lucas Escolá, al final de su carrera, que fue dada a conocer por el historiador Romero Santamaría (1999), en la que el veterano fotógrafo relataba sus difíciles inicios en la profesión, el historiador catalán descubrió la presencia, hasta hoy ignorada, del Dr. Jaime Ferrán habitando en Zaragoza:

[Entrevistador] - ¿Quién le facilitó a usted los secretos del laboratorio, tan preciados entonces y tan vulgarizados hoy?

[Lucas Escolá] - Fue el doctor Ferrán, con el que intimé. Vivía en la estación de Cappa, hoy Utrillas, y una tarde, después de haberlo hecho confidente de mis dificultades, me llevó a su casa, donde me explicó algunas recetas de revelado y preparación de placas al colodión húmedo, único procedimiento que entonces se usaba, y me entregó un libro que trataba sobre fotografía .

${ }^{6}$ Heraldo de Aragón, 23 de enero de 1930, "Las bodas de oro de un fotógrafo". 
Entre la documentación del archivo Ferrán, el investigador Tío i Sauleda ha podido encontrar la prueba documental que constata la presencia del doctor catalán en Zaragoza, en los días inmediatos a la publicación de la Instantaneidad en fotografía ${ }^{7}$, que había tenido lugar en Tortosa, entre agosto y septiembre de 1879. Desde esa última fecha y hasta el 22 de diciembre de ese mismo año, Ferrán habitó en Zaragoza, donde estableció un consultorio médico-quirúrgico, en el principal de la calle Cerdán, 63, como atestigua la publicidad impresa de dicho consultorio, editada en la Imprenta del Hospicio Provincial de Zaragoza:

\section{"CONSULTORIO MÉDICO-QUIRÚRGICO \\ Dirigido por el \\ MÉDICO-OCULISTA Y ELECTROTERAPA \\ D. J. FERRÁN}

Permanecerá en esta Ciudad hasta dejar curados o restablecidos los enfermos que se presenten antes del 22 de Diciembre.

[...] Horas de consulta, de 9 a 1

Para los desahuciados y crónicos, de 5 a 7

CERDÁN, 63, Principal

Zaragoza, Imprenta del Hospicio Provincial"8

Los inicios de la amistad y complicidad establecida gracias a la afición por la fotografía entre Santiago Ramón y Cajal y Jaime Ferrán debe, por tanto, remontarse a la etapa zaragozana de Ferrán, quien tal vez conoció al aragonés a través de su común amigo, el fotógrafo Lucas Escolá. Sin embargo, como es bien sabido, especialmente a partir de la campaña de la vacunación contra el cólera en Valencia del año 1885, impulsada por el Dr. Ferrán, y del informe contrario a la efectividad de dicha vacuna que elaboró Ramón y Cajal por en-

\footnotetext{
${ }^{7}$ La instantaneidad en fotografía por J. Ferrán e I. Paulí. Emulsión de bromuro de plata con gelatina, diez veces más rápida que el colodión húmedo. Emulsión a las féculas por los autores. Recientes trabajos del Dr. Monckoven, Tortosa, Establecimiento Tipográfico de Pedro Llanes, Moncada, 36, junto a la Purísima, 1879.

${ }^{8}$ Archivo Ferrán, Museo de Historia de la Medicina de Cataluña, Barcelona.
} 
cargo de la Diputación de Zaragoza, surgieron diferencias irreconciliables entre ambos, que incluso se vieron acrecentadas durante el periodo barcelonés del aragonés. Hasta tal punto llegaron esas malas relaciones entre ambos que Santiago Ramón y Cajal en sus memorias omitió cualquier referencia acerca de la amistad inicial existente entre ambos. Y, como parece demostrado, silenció su nombre como autor del "libro moderno" sobre la instantaneidad en fotografía, publicación pionera en la difusión entre los aficionados españoles de la moderna técnica del gelatino-bromuro de plata.

Creo, por tanto, que es un acto de justicia restituir el nombre del Dr. Ferrán, no solo como coautor, pionero en la traducción al español y puesta al día de los estudios sobre la instantaneidad en fotografía, sino también como parte esencial en la génesis de esas primeras experiencias fotográficas nacionales con respecto a la emulsión al gelatino-bromuro de plata, que fueron llevadas a cabo en Zaragoza por nuestro admirado, Santiago Ramón y Cajal, y su colaborador, el fotógrafo Lucas Escolá Arimany.

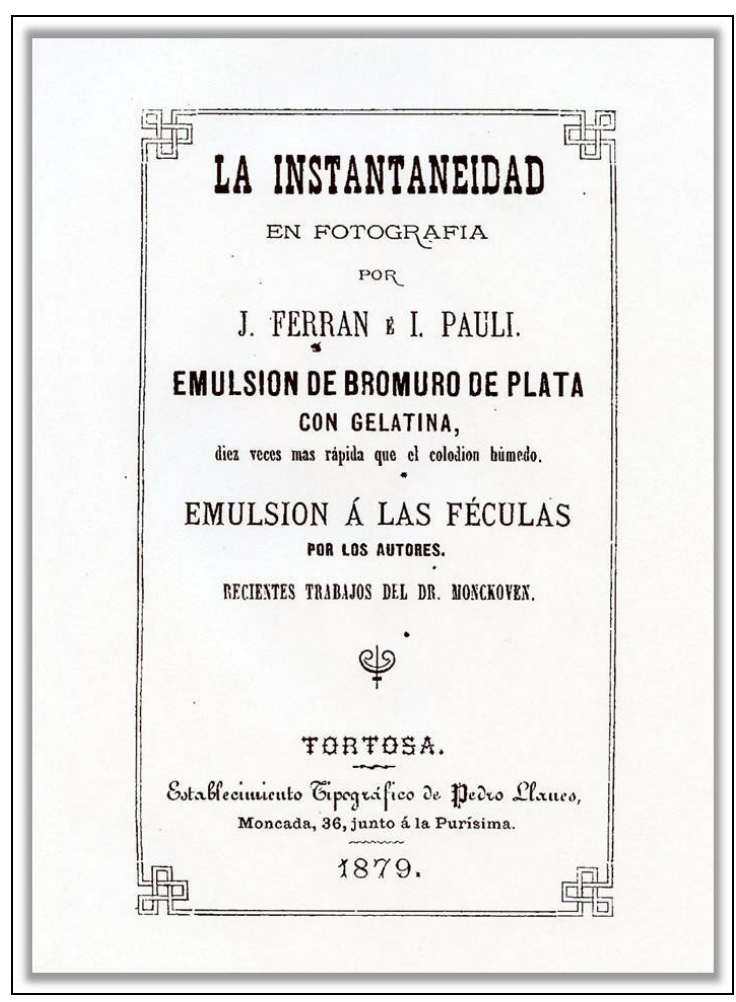

52
Fig. 8.

Portada del libro de J. Ferrán e I. Paulí, La instantaneidad en fotografía (Tortosa, 1879). 


\section{La edición de tarjetas postales, entre 1900 y 1915}

Aunque la tarjeta postal nació en Austria en 1869, no se implantó en España hasta el 1 de noviembre de 1873. Sin embargo, el origen de la tarjeta postal ilustrada es más tardío y para encontrar las primeras postales ilustradas con vistas de ciudades españolas debemos esperar hasta el año 1892, en que están documentadas diferentes tarjetas postales con imágenes de Madrid o de las Palmas de Gran Canaria9. La Fototipia de Hauser y Menet, establecida en Madrid desde 1890, fue la editorial pionera en nuestro país en la edición de tarjetas postales.

Como venimos diciendo, la culminación del viaje a España de la firma J. Lévy vino a coincidir prácticamente con el nacimiento en España de la tarjeta postal ilustrada. Así que, ante la constatación de un descenso progresivo en las ventas del voluminoso material fotográfico almacenado en sus formatos tradicionales, hacia 1900 y siguiendo el modelo de actuación de otras empresas fotográficas coetáneas, la firma parisina recondujo su estrategia editorial y finalmente se decidió a estampar diferentes y sucesivas ediciones de tarjetas postales a partir de las fotografías tomadas en España en la década de 1880. Para su datación tenemos que tener en cuenta el cambio de normativa establecido por la Unión Postal Universal en 1905 y generalizado para todos los países, por el que se autorizaba dividir el reverso de las tarjetas postales en dos partes, la izquierda para el texto del mensaje y la derecha para la dirección del destinatario. Esta nueva estructura de las tarjetas postales, con el "reverso dividido", ayuda enormemente a la hora de establecer la cronología de estas primeras postales ilustradas.

Una importante selección de estas instantáneas españolas protagonizará hasta tres diferentes series de tarjetas postales estereoscópicas. Se trata de las series denominadas "L'Espagne / España", "Andalousie / Andalucía" y "Nord de l'Espagne / Norte de España", respectivamente. Todas ellas están compuestas por 24 fototipias de vistas de las diferentes ciudades, en algunos casos coloreadas a mano. En varias colecciones particulares hemos podido encontrar para las tres series, ediciones tanto con el reverso dividido, como sin dividir, lo que da a entender que las primeras ediciones de estas series debemos datarlas en torno a 1900, y sus reediciones posteriores, con el reverso dividido, ya a partir de 1905.

${ }^{9}$ Ver el trabajo pionero en el tema de Teixidor Cadenas (1999). 

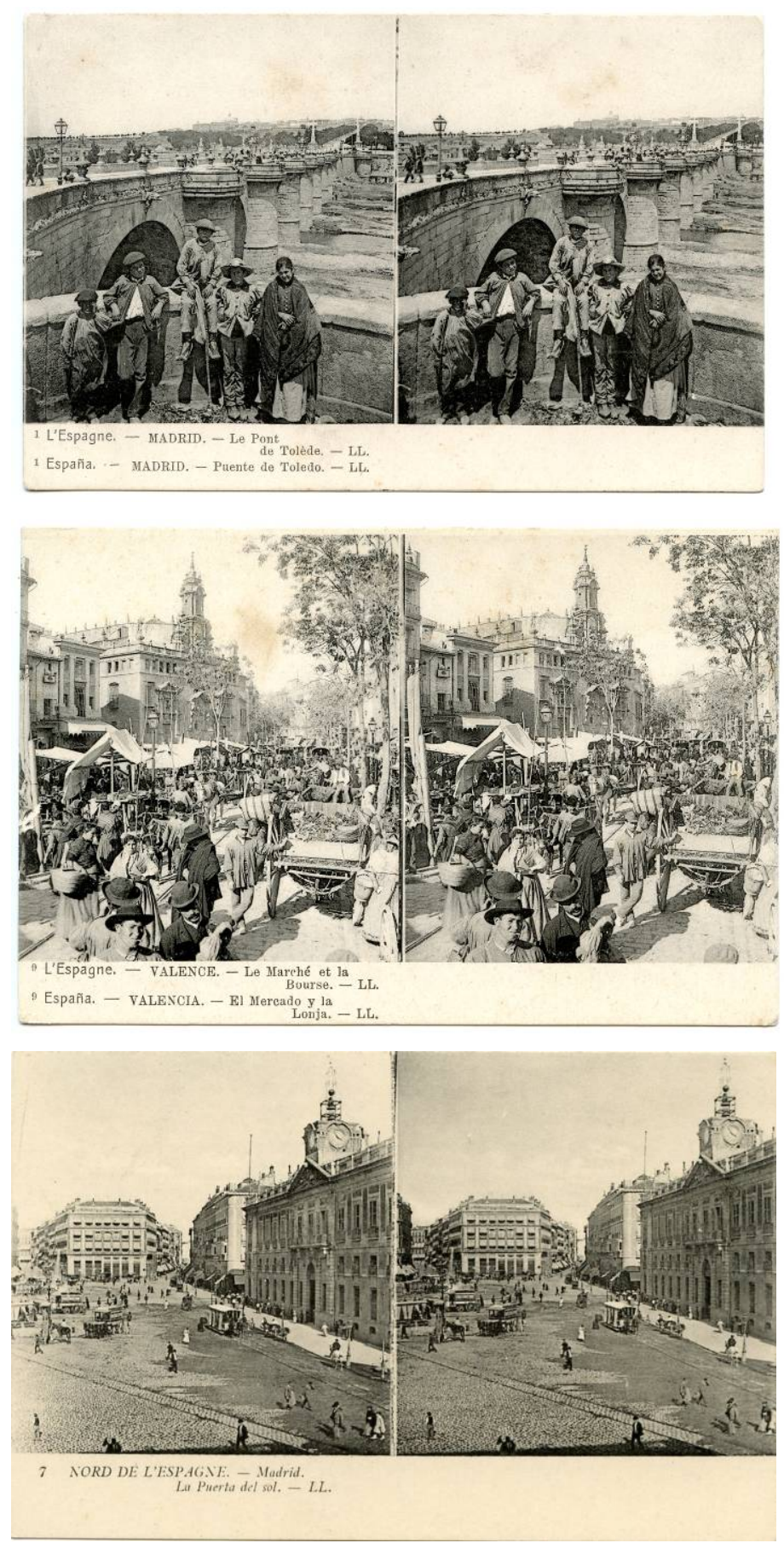

Figs. $9-11$ :

Tarjetas postales esteroscópicas, fototipia, ca. 1905.

№ 1. España / L'Espagne. Madrid. Puente de Toledo.

№ 9. España / L'Espagne. Valencia. El Mercado y la Lonja.

№ 7. Nord de l'Espagne. Madrid. Puerta del Sol 


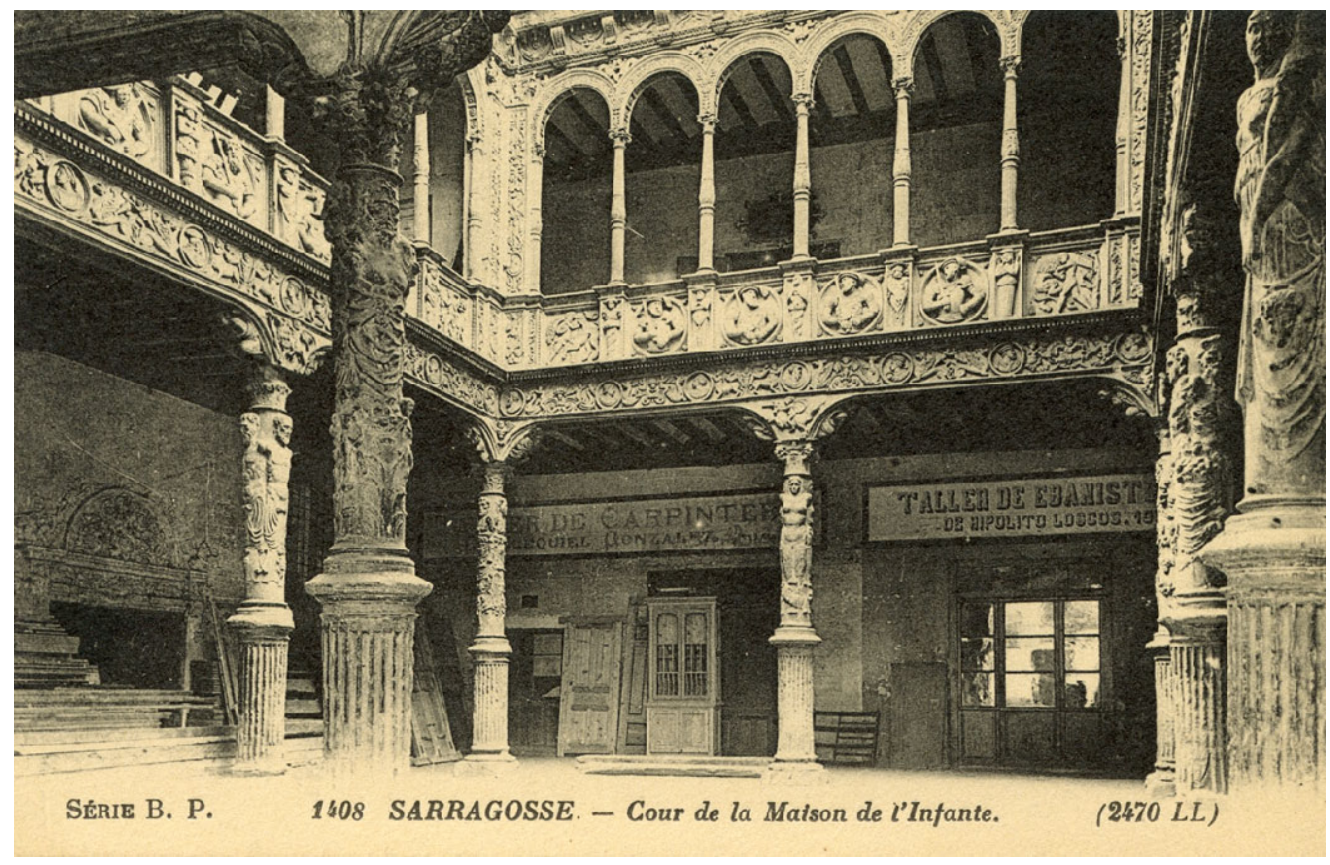

Fig. 12: № 1408. B.P. Zaragoza. Patio de la Casa de la Infanta, (2470, LL)

Tarjeta postal esteroscópica, fototipia, ca. 1905

Hay que advertir, que en el caso de la serie "Nord de l'Espagne", se constata una curiosa doble errata que protagoniza una imagen zaragozana. Por un lado, el monumento histórico que se reproduce es indiscutiblemente el Torreón de la Zuda, sin embargo, el texto impreso reza: "Murcia, Vicille Maison", ciudad que, como es lógico, tampoco podía formar parte de la serie "Norte de España". Sin embargo, la reproducción más fidedigna con respecto a las instantáneas españolas de la década de 1880, es la muy exclusiva serie denominada B.P., editada también bajo las siglas "LL", como en el caso anterior, a partir de 1905, ya que presenta los reversos divididos. Debo añadir, además, que ninguna de las tarjetas postales de esta serie que he podido ver había sido circulada (es decir, que no contiene inscripciones manuscritas, fechas, sellos, ni matasellos), lo que dificulta el poder establecer una cronología más precisa.

La consolidación del hábito del envío de tarjetas postales como una de las formas de correo más utilizadas, así como la moda del coleccionismo e intercambio de las diferentes ediciones de series de tarjetas postales, propició que 
la oferta de tarjetas postales ilustradas con imágenes actualizadas de las diferentes ciudades de España se multiplicara. Ante este panorama, la serie B.P. realizada a partir de imágenes de mediados de la década de 1880, que venía comercializando la casa Lévy desde 1905, se quedaría pronto desfasada.

Por ello, la compañía y editorial parisina planificó nuevos viajes a la península y elaboró una nueva serie de vistas fotográficas de sus diferentes ciudades, que fueron editadas hacia 1910, también bajo las siglas "LL". En el caso de ciudades como Zaragoza, la nueva serie se compuso de 33 imágenes y en ella se constatan algunos de los cambios que había experimentado la fisonomía de la ciudad desde principios de siglo y, sobre todo, a raíz de la Exposición Hispano-Francesa de 1908.

Junto a esa serie editada en negro, coetáneamente, alrededor de 1910, fue comercializada una segunda serie de tarjetas postales en color, con las mismas vistas que la serie impresa en negro. Sin embargo, cuando se cotejan las postales de las diferentes series correspondientes a la misma escena urbana, se advierte que aunque el punto de vista del fotógrafo es el mismo, sin embargo, ambas imágenes son ligeramente diferentes, ya que fueron tomadas sucesivamente con algunos segundos de diferencia entre una y otra.

Con el objeto de mantener esta serie actualizada se irían incorporando puntualmente, a partir de 1915, algunas nuevas imágenes aisladas, sin numeración, que renovaban la serie y recogían las transformaciones más evidentes en la fisonomía urbana de las diferentes ciudades.

\section{Apéndice documental}

Relación numerada de las tres series de tarjetas postales estereoscópicas, algunas de ellas coloreadas a mano, editadas en torno a 1900 - 1905 por la casa Levy $\mathcal{E}$ ses files, a partir de los negativos originales tomados durante la segunda mitad de la década de 1880. La relación de cada una de estas tres series ha sido confeccionada, no a partir de catálogos editados, sino en base a la recopilación de las tarjetas postales que, a lo largo de estos años he podido ir conociendo y, en algunos casos, adquiriendo. Por ello, algunos de sus títulos todavía no han podido ser cumplimentados. 


\begin{tabular}{|c|c|c|}
\hline 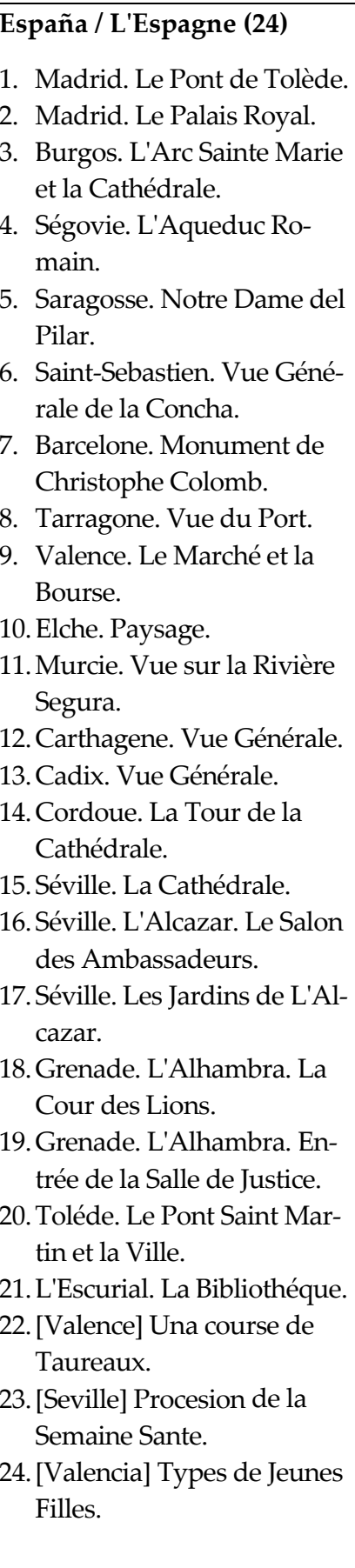 & 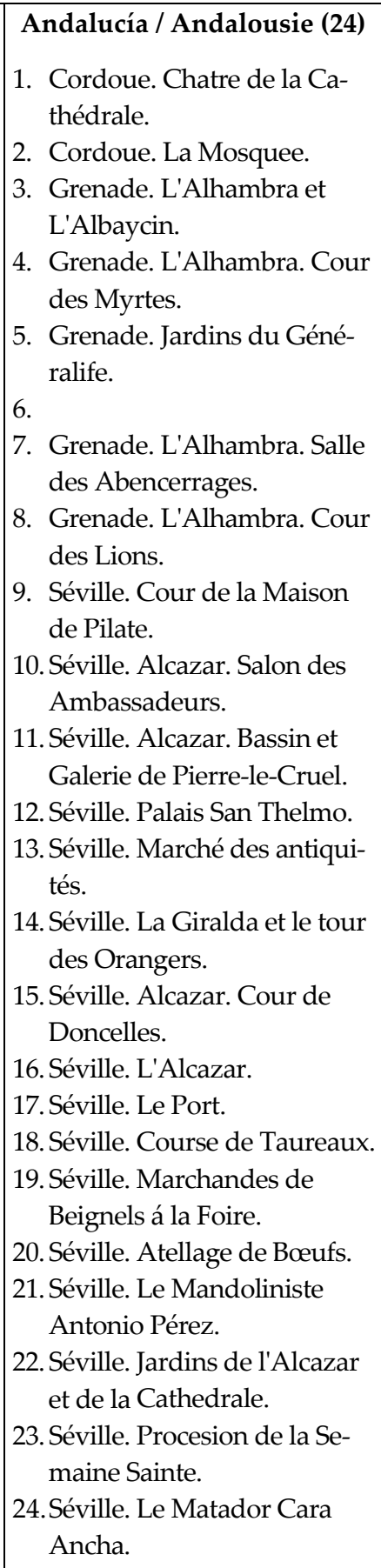 & $\begin{array}{l}\text { Norte de España / } \\
\text { Nord de l'Espagne (24) } \\
\text { 1. Madrid. Le Palais Royal. } \\
\text { 2. Madrid. Le Pont de Toléde. } \\
\text { 3. L'Escurial. La Bibliothéque. } \\
\text { 4. Burgos. La Cathédrale. } \\
\text { 5. Zaragoza. Notre-Dame de } \\
\text { Pilar. } \\
\text { 6. Toléde. Vue générale. } \\
\text { 7. Madrid. La Puerta del Sol. } \\
\text { 8. Ségovia. L'Alcazar. } \\
\text { 9. Ávila. Les Remparts. } \\
\text { 10. La Granja. Le Château. } \\
\text { 11. La Granja. Le Parc. } \\
\text { 12. Madrid. Les Cortes. } \\
\text { 13. } \\
\text { 14. Burgos. Vue générale. } \\
\text { 15. Burgos. Les Tombeaux. } \\
\text { 16. Murcie. Vicille Maison [Za- } \\
\text { ragoza. Torre de la Zuda]. } \\
\text { 17. } \\
\text { 18. Burgos. Tour de la Cathé- } \\
\text { drale. } \\
\text { 19. Valladolid. Le Cloitre } \\
\text { Saint-Jérôme. } \\
\text { 20. } \\
\text { 21. Madrid. Le Château-Royal. } \\
\text { 22. Burgos. L'Arc Sainte-Marie. } \\
\text { 23. } \\
\text { 24. Madrid. Rue d'Alcala. }\end{array}$ \\
\hline
\end{tabular}




\section{Bibliografía}

CAMERON, John. B. (2007): "Léon, Moyse \& Lévy, Isaac; Ferrier, Claude-Marie; and Charles Soulier". Enciclopedia of Nineteenth-Century Photography. John Hannavy, Escocia, Reino Unido, págs. 850-852.

FERNÁNDEZ RIVERO, J. A. (2011): "Ferrier-Soulier Editores". En VV.AA.: Una imagen de España. Fotógrafos estereoscopistas franceses [1856-1867]. TF. Editores y Fundación Mapfre, Madrid.

GARÓFANOSÁNCHEZ, Rafael (2002): Andaluces y marroquíes en la colección fotográfica Lévy (1888-1889). Diputación de Cádiz, Cádiz.

HERNÁNDEZ LATAS, J. A. (2012): Zaragoza en la mirada ajena. Instantáneas del archivo Roger-Viollet de Paris: J. Léry et Cie, 1889. Cortes de Aragón, Zaragoza [edición digital] Huguet CHANZÁ, J. (1999): Valencia en 1888. Ayuntamiento de Valencia, Valencia MÁRQUEZ, Miguel B. (2004): "Santiago Ramón y Cajal, algo más que un fotógrafo". Ámbitos. 11-12 - 1er y 2º Semestres de 2004, págs. 139-153.

MCCAULEY, Elizabeth Anne (1994): Industrial Madness. Commercial Photography in Paris, 1848-1871. Yale University Press, New Haven and London.

MEGNIN, Michel (2008): "Léon \& Levy, puis Levy \& Fils (L.L.)". Dictionnaire des orientalistes de langue française. Khartala, Nouvelles notices, Paris.

RAMÓN Y CAJAL, Santiago (1901): Recuerdos de mi vida. Mi infancia y juventud, cap. XXVII (1 $1^{\mathrm{a}}$ ed., 1901).

ROMERO SANTAMARÍA, A. (1999): La fotografía en Aragón. Ibercaja, Zaragoza.

SÁNCHEZ GÓMEZ, Carlos (2011): “Los editores Ferrier-Soulier y Gaudin”, en AAVV. Una imagen de España. Fotógrafos estereoscopistas franceses (18561867).TF Editores y Fundación Mapfre. Madrid.

SÁNCHEZ GÓMEZ, Carlos (2012): "El patio de los Leones de la Alhambra Imagen fotográfica e historicidad de un espacio monumental". Cuadernos de La Alhambra, $\mathrm{n}^{\circ} 44$, Granada.

SERRANO PARDO, Luis (2001): "Lucas Escolá". Pasarela. Artes Plásticas. Zaragoza, no 11, mayo de 2001, págs. 5-16.

TeIXIDOR CADENAS, Carlos (1999): La Tarjeta Postal en España, 1892-1915. Espasa Calpe, S.A., Madrid.

TIÓ I SAULEDA, Salvador (2007): "Ferrán i Paulí: La instantaneidad en Fotografía". Quaderns d'Historia de l'Enginyeria. Vol. VIII, 2007, págs. 51-269.

WING, Paul (1996): Stereoscopes The first one hundred years. Transition Publishing, Nashua, New Hampsire. 